\title{
Sodium Nitroprusside inhibits HEK293 Cell Growth by cGMP-Dependent and Independent Mechanisms
}

\author{
Georg Sager ${ }^{1}$, Elisabeth Sundkvist' ${ }^{1}$, Ragnhild Jaeger ${ }^{1}$, Roy-Andre Lysaa ${ }^{1}$, \\ Ole-Martin Fuskevaag ${ }^{2}$ \\ ${ }^{1}$ Medical Pharmacology and Toxicology, Department of Medical Biology, Faculty of Health Sciences, \\ University of Tromso, Tromso, Norway \\ ${ }^{2}$ Department of Laboratory Medicine, Division of Diagnostic Services, University Hospital of North Norway, \\ Tromso, Norway \\ Email: georg.sager@uit.no
}

Received 5 January 2014; revised 16 February 2014; accepted 6 March 2014

Copyright (C) 2014 by authors and Scientific Research Publishing Inc.

This work is licensed under the Creative Commons Attribution International License (CC BY). http://creativecommons.org/licenses/by/4.0/

(c) (i) Open Access

\section{Abstract}

The acute and chronic effects of sodium nitroprusside (SNP) are well characterized for vascular smooth muscle cells (VSMC). Stimulation of soluble guanylyl cyclase (sGC) gives a rapid elevation of intracellular cGMP levels and relaxation of VSMC. The antiproliferative effect of SNP needs days to develop. In the present study human embryonic kidney (HEK 293) cells were used to study the growth after repeated exposure to SNP. A dose-dependent antiproliferative effect was evident and after 5 days with an IC 50 value of $108 \mu \mathrm{M}$. Cyclic GMP was able to mimic the antiproliferative effect of SNP on HEK293 cells. When cGMP $(1000 \mu \mathrm{M})$ was added to the cell culture medium for 5 days

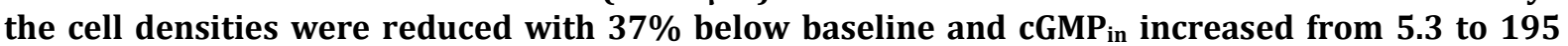
pmol/107 cells. The interaction with the non-selective PDE (cyclic nucleotide phosphodiesterase) inhibitor 3-isobutyl-1-methylxanthine (IBMX) was tested after three days. IBMX alone (1000 $\mu \mathrm{M})$ reduced cell densities with $48 \%$ and elevated cGMP in (from 5.2 to $9.3 \mathrm{pmol} / 10^{7} \mathrm{cells}$ ). The effect of $10 \mu \mathrm{M}$ SNP was reinforced on proliferation (from $13 \%$ to $90 \%$ ) and elevation of cGMP levels (from 7.6 to $\left.13.5 \mathrm{pmol} / \mathbf{1 0}^{7} \mathrm{cells}\right)$. A corresponding effect was observed after addition of $1000 \mu \mathrm{M}$ cGMP and $1000 \mu \mathrm{M}$ IBMX for 3 days. The antiproliferative effect of cGMP increased from $30 \%$ to $\mathbf{8 9 \%}$ and the cGMP ${ }_{\text {in }}$ increased from 240 to $480 \mathrm{pmol} / \mathbf{1 0}^{7}$ cells. However, additional mechanisms exist for the antiproliferative effect of SNP. One of these is the intracellular oxidative effect which includes production of S-nitrosoglutathione. The fall in ratios between GSH and GSSG from 260 to 85 after $100 \mu \mathrm{M}$ SNP exposure is compatible with such a mechanism since cGMP (1000 $\mu \mathrm{M})$ added to the culture medium did not change the ratio. This study shows that the antiproliferative effects of SNP on HEK293 cells are mediated through cGMP-dependent and cGMP-independent mechanisms. The concentration-dependent effects develop over time. HEK293 cells had an efficient ef- 
flux system for cGMP and the use of inside-out vesicles (IOVs) showed high affinity ATP-dependent cGMP transport with a $K_{m}$ value of $2.3 \mu \mathrm{M}$. The antiproliferative effect of SNP was correlated to cGMPex/in.

Keywords

HEK293 Cells; Growth; SNP; cGMP; IBMX; Glutathione

\section{Introduction}

The primary nitric oxide receptor is soluble guanylate cyclase (sGC) with stimulation of cGMP synthesis. In addition, nitric oxide donors like sodium nitroprusside (SNP) modulate various key-enzymes and S-nitrosylate intracellular proteins with direct effects on gene expression [1]. In pharmacotherapy, nitric oxide donors are used as vasodilators but are also believed to remodel vascular smooth muscle cells (VSMC) with a favorable effect on hypertension. Several in vitro studies have shown that SNP and similar sGC-stimulating agents inhibit growth of VSMC in a dose dependent manner [2]-[5]. The effect was explained by increased intracellular cGMP levels $\left({ }^{(c G M P}{ }_{\text {in }}\right)$ [2] [3] with inhibition of DNA synthesis [6] and a pro-apoptotic action, as well [4]. The idea that elevation of cGMP $_{\text {in }}$ gives an antiproliferative effect was substantiated after selective inhibition of phosphodiesterase activity [6] [7]. Finally, PKG activation by cGMP retards cell cycle and induces apoptosis [8]. Several studies have focused on the antiproliferative effects due to stimulated cGMP synthesis and inhibition of cGMP degradation. A third component is also involved in the biokinetics, the cellular efflux of cGMP. Members of the multidrug resistance associated proteins (MRP) are responsible for cGMP extrusion including MRP4 [9] and MRP5 [10]. The cells employed in the present study, have proved to be suitable for studies of cyclic nucleotide transport [11] [12]. In this study we characterized cell growth under the influence of cGMP elevating agents with relation to $\mathrm{cGMP}_{\mathrm{in}}$, the transmembrane cGMP concentration ratio $\left(\mathrm{cGMP}_{\mathrm{ex} / \mathrm{in}}\right.$ ), and intracellular reduced (GSH) and oxidized glutathione (GSSG) concentrations.

\section{Methods}

\subsection{Materials}

SNP, cGMP and 3-isobutyl-1-methylxanthine (IBMX) were obtained from Sigma-Aldrich Co (Schnelldorf, Germany). Other chemicals were of analytical grade.

\subsection{Cell Culture}

HEK293 cells were cultured in Dulbecco's modified Eagle's medium supplemented with $10 \%$ new-born calf serum, penicillin $(100 \mathrm{IU} / \mathrm{ml})$ and streptomycin $(100 \mu \mathrm{g} / \mathrm{ml})$. The cells were adherent after $24 \mathrm{~h}$ and the culture medium including cGMP-elevating agents was replaced daily the next five days. The cells were harvested after trypsination, washed before manual counting (Burker chamber) and freezing $\left(-22^{\circ} \mathrm{C}\right)$.

\subsection{Cyclic GMP Assays}

The $\left[{ }^{125} \mathrm{I}\right]$-cGMP RIA kit (Perkin Elmer Inc., Boston, MA) was employed. The samples and standards were acetylated according to the protocol from manufacturer. For concentrations extending the linear part of the standard curve, the samples were serially diluted before reanalysis. High concentrations were also determined in a HPLC-assay with UV detection (254 nm). The equipment comprised a Dionex P680 pump and Ultimate 8000 UV detector, Thermo Fisher Scientific Inc., CA, a Waters Novapak $25 \mathrm{~cm}$ C18 column with a Waters Symmetry guard column (Waters Norway. Kjeller, Norway). The samples (200 $\mu \mathrm{l})$ were mixed with $200 \mu \mathrm{l}$ 1\% (w/v) trichloroacetic acid and $50 \mu \mathrm{l}$ internal standard (8-Br-cGMP) and adding $\mathrm{KOH} / \mathrm{KHCO}_{3}$ (1:1) to achieve $\mathrm{pH}$ 7.0. The mobile phase comprised $15 \% 20 \mathrm{mM}$ methanol in $20 \mathrm{mM} \mathrm{K} \mathrm{HPO}_{4} / \mathrm{KH}_{2} \mathrm{PO}_{4}$, pH 6.6. The flow rate was 1.2 $\mathrm{ml} / \mathrm{min}$ and temperature was $20^{\circ} \mathrm{C}-22^{\circ} \mathrm{C}$. 


\subsection{3-Isobutyl-1-methylxanthine Assay}

The levels of IBMX were determined in a LC-MS/MS assay (Waters Alliance 2695, Waters Corp., Milford, MA), Quattro Micro tandem quadrupole (Waters, Manchester, UK). The chromatography was performed on a $2.1 \times 20 \mathrm{~mm}$ Waters Xterra MS C18 $(3.5 \mu \mathrm{m} 2.1 \times 20 \mathrm{~mm})$ column at $25^{\circ} \mathrm{C}$. The mobile phase comprised $50 \%$ methanol in $0.1 \%$ aqueous formic acid with a flow rate of $0.25 \mathrm{ml} / \mathrm{min}$ (isocratic). Ionization was achieved using electrospray in positive mode. Calibration curves and controls ranging from 0.5 to $32 \mu \mathrm{M}$ were prepared by dilution of the stock solution of IBMX in culture medium or PBS. Double liquid-liquid extraction was employed to determine IBMX levels in the cell pellets and culture medium. Samples, standards and controls were prepared by adding $50 \mu \mathrm{l} 100 \mathrm{mM} \mathrm{H}_{2} \mathrm{CO}_{3}$ (pH 11.5) and $50 \mu \mathrm{l}$ of internal standard (2 $\mu \mathrm{M}$ naloxone) to $100 \mu \mathrm{l}$ of the sample. IBMX was extracted with $1 \mathrm{ml}$ of n-hexane/ethyl acetate (7:3). The tubes were vortexed for $1 \mathrm{~min}$ and centrifuged at $3000 \mathrm{x}$ g for $4 \mathrm{~min}$. The organic layer $(750 \mu \mathrm{l}$ ) was transferred to new tubes and mixed with $200 \mu \mathrm{l} 2 \%$ formic acid before centrifugation. The aqueous layer $(100 \mu \mathrm{l})$ was finally transferred to LC-vials and analyzed. The injection volume was set to $5 \mu$ and the injection interval was 2 min. Quantitative analysis was done in the multiple reaction monitoring mode with the following transitions: m/z 223 to 167 and 328 to 3010 for IBMX and naloxone, respectively. The dwell time was set to $100 \mathrm{~ms}$ for each transition. The method showed linearity for the calibration curve with $\mathrm{r}^{2}>0.99$.

\subsection{Assay of Reduced and Oxidized Glutathione}

To avoid oxidation of GSH after cell harvesting a blocking solution ( $250 \mu \mathrm{l}$ of $60 \mathrm{mM}$ NEM, 1.2\% (v/v) DMSO, $152 \mathrm{mM} \mathrm{NaCl}, 1 \mathrm{mM}$ acetic acid) was added to $500 \mu \mathrm{l}$ cell suspension (or to GSH-GSSG standard) and incubated for $30 \mathrm{~s}$. A mixture of equal volumes ( $250 \mu \mathrm{l})$ of GSH internal standard and GSSG internal standard was added and the suspension was incubated for another $30 \mathrm{~s}$. Afterwards the cells were lysed by the addition of trichloroacetic acid before removal of unreacted NEM by extraction with $10 \mathrm{ml}$ of dichloromethane. The water phase was collected and used for LC-MS/MS analysis. The GSH internal standard was isotope labeled (Glycine- ${ }^{13} \mathrm{C}_{2},{ }^{15} \mathrm{~N}$ )-glutathione from Cambridge Isotope Laboratories Inc., Andover, MA). The GSSG internal standard was synthesized and prepared as described [13] with some modifications. The LC-MS/MS assay of GSH and GSSG were performed as previously described by New and Chan [14]. The analytical equipment consisted of Waters AcquityTM UPLC system (Waters, Milford, MA) with a binary solvent delivery system interfaced to Waters Micromass ${ }^{\circledR}$ Quattro Premier ${ }^{\mathrm{TM}}$ XE benchtop tandem quadrupole mass spectrometer (Waters, Manchester, UK). The chromatography was performed on a $2.1 \times 100 \mathrm{~mm}$ Waters Acquity ${ }^{\mathrm{TM}} \mathrm{HSS}$ T3 (C18) column with a mobile phase (maintained at $50^{\circ} \mathrm{C}$ ) of $0.1 \%$ formic acid in water (solvent $\mathrm{A}$ ) and $0.1 \%$ formic acid in acetonitrile (solvent B) with a flow rate of $0.45 \mathrm{ml} / \mathrm{min}$. The run with solvent A was composed of an isocratic delivery of $1 \%$ solvent B for the first 2 min, a linear gradient from $1 \%-30 \%$ with solvent B over 1.5 min, and finally a second linear gradient from 30\% - 95\% with solvent B over $1 \mathrm{~min}$. The protein concentrations were determined by the bicinchonic acid (BCA) method [15] with an assay from Fisher Scientific (Oslo, Norway).

\subsection{Preparation of Inside-Out Vesicles and Transport Experiments}

Inside-out vesicles (IOVs) from HEK293 cells were essentially prepared as described earlier [16] with a cocktail of proteinase inhibitors; AEBSF, pepstatin A, E-64, bestatin, leupeptin and aprotinin (Sigma-Aldrich Co, Schnelldorf, Germany). The transport experiments were performed at $37^{\circ}$ with $\left[{ }^{3} \mathrm{H}\right]$-cGMP (Perkin Elmer Inc., Boston, MA) combined with unlabelled cGMP (1.2 - 7.2 $\mu \mathrm{M}$ ), membrane vesicles, $10 \mathrm{mM} \mathrm{MgCl}$, $\mathrm{PBS}$ (pH 7.4) In absence or presence of $2 \mathrm{mM}$ ATP. The uptake of cGMP was terminated after $30 \mathrm{~min}$ by addition of $10 \mathrm{ml}$ ice-cold $30 \mathrm{mMNaF} / 0.5 \mathrm{mM}$ Tris-HCl. The vesicles were sedimented $\left(16,300 \times \mathrm{g}\right.$ for $20 \mathrm{~min}$ at $\left.4^{\circ} \mathrm{C}\right)$, washed, resuspended in $1 \mathrm{ml}$ water and frozen $\left(16 \mathrm{~h}\right.$ at $\left.-20^{\circ} \mathrm{C}\right)$. After thawing and sedimentation $(15,000 \times \mathrm{g}$ for $30 \mathrm{~min}$ at $4^{\circ} \mathrm{C}$ ), the radioactivity was determined in $0.8 \mathrm{ml}$ of the supernatant mixed with $10 \mathrm{ml}$ Ultima Gold XR scintillation Solution (Perkin Elmer Inc., Boston, MA) in a 1900 Packard liquid scintillation counter. The protein concentrations were determined by the coomassie blue method [17] using reagents from Bio-Rad laboratories (Oslo, Norway) with BSA (Sigma-Aldrich Co, Schnelldorf, Germany) as standard.

\subsection{Calculation and Statistics}

The $\mathrm{IC}_{50}$-values (concentration of SNP needed to reduce the total cell densities to $50 \%$ of baseline values) were 
calculated according to Chou [18]. The results are presented as mean value \pm SEM $(n=3)$ if not stated otherwise.

\section{Results}

\subsection{SNP Effects on Cell Growth, and Levels of cGMP, GSH and GSSG}

SNP reduced cell densities in a concentration and time-dependent manner (Figure 1). After daily exposure to SNP for five days an IC $_{50}$ value of $108 \pm 63 \mu \mathrm{M}$ was obtained. In absence of active agent cGMP ${ }_{\text {in }}$ declined during the culture period from $26.9 \pm 7.5$ to $3.4 \pm 0.3 \mathrm{pmol} / 10^{7}$ cells. The levels after SNP-stimulation did also decline during this period (results not shown). Table 1 shows cGMP ${ }_{\text {in }} 24 \mathrm{~h}$ after the last addition of SNP. Only the highest concentration was somewhat higher than the baseline value. This is compatible with the observation that the peak concentration of cGMP $_{\text {in }}$ occurs few minutes after SNP addition to rat lung fibroblasts and with declining levels afterwards [19]. The observation that the $\mathrm{cGMP}_{\mathrm{ex}}$ was 8 times higher than $\mathrm{CGMP}_{\text {in }}$ shows an unidirectional extrusion of cGMP 24 after addition of $100 \mu \mathrm{M}$ SNP (Table 1). The accumulation of extracellular cGMP during the exposure period may explain why the fraction of surviving cell was inversely related to $\mathrm{CGMP}_{\mathrm{ex} / \mathrm{in}}$ after 5 days (slope $=-0.053$ and intercept $=0.92, r=0.99$ ).

In a follow-up experiment IBMX was introduced to determine if and how the antiproliferative effect of SNP was modulated. The combination of SNP $(10 \mu \mathrm{M})$ and IBMX $(1000 \mu \mathrm{M})$ caused complete cell death after 5 days. Due to this, the data after three days were employed to obtain measurable cGMP ${ }_{\text {in }}$. Figure 2 shows that IBMX alone had a clear antiproliferative effect and potentiated the effect of SNP. In agreement with these observations IMBX alone or combined with SNP gave distinct increases of $\mathrm{CGMP}_{\text {in }}$ (Table 2). After addition of SNP a minor increase of $\mathrm{cGMP}_{\mathrm{ex} / \mathrm{in}}$ was seen whereas IBMX alone and in combination with SNP gave a relative cGMP $_{\text {ex }}$ increase of 15 and 85, respectively. There may be two reasons for this effect. Firstly, increased substrate

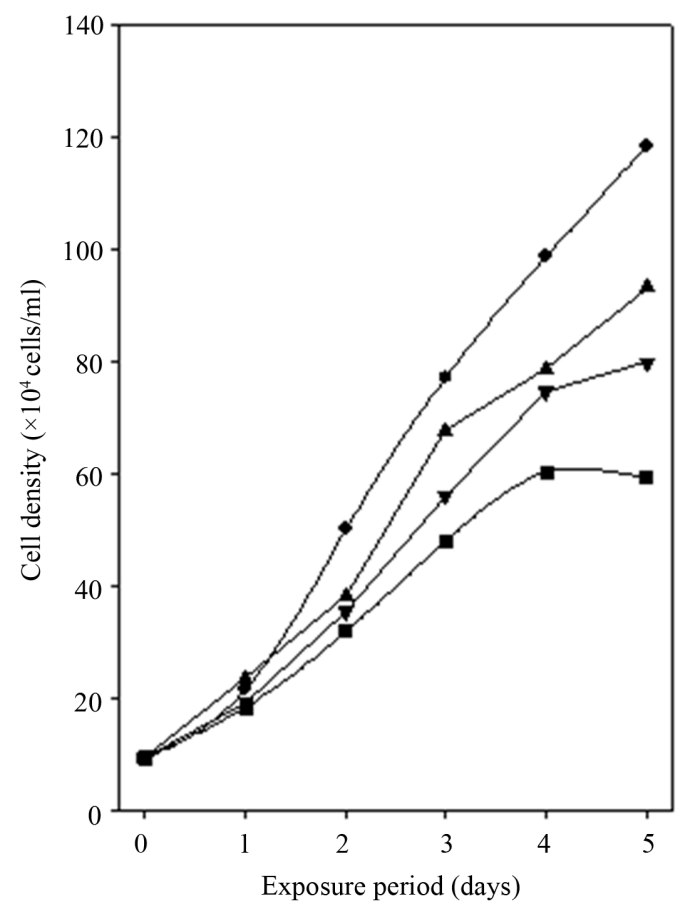

Figure 1. After removal of old medium freshly prepared SNP $(1-100 \mu \mathrm{M})$ was added daily to HEK293 cells in culture. After 5 days the baseline cell densities had increased from $4 \times 10^{4}$ to $119 \pm 12 \times 10^{4}$ cells $/ \mathrm{ml}$. The results are presented as mean value of cell densities from three time-independent experiments. Baseline $(\bullet), 1 \mu \mathrm{M}(\boldsymbol{\Delta}), 10 \mu \mathrm{M}(\boldsymbol{\nabla})$ and 100 $\mu \mathrm{M}$ SNP (匹). 
Table 1. Freshly prepared SNP was added daily and the intra- and extracellular concentrations were determined $24 \mathrm{~h}$ after the addition. The respective extra- to intracellular concentration ratio was $6.5 \pm 1$.3. The results are presented as mean value $\pm \operatorname{SEM}(n=3)$ after 5 days with repeated SNP exposure.

\begin{tabular}{ccc}
\hline & cGMP $_{\text {in }}$ pmol/10 & \\
\hline $\mathrm{SNP}(\mu \mathrm{M})$ & & \\
0 & $3.4 \pm 0.3$ & $2.3 \pm 0.2$ \\
1 & $4.0 \pm 0.5$ & $2.5 \pm 0.5$ \\
10 & $3.6 \pm 0.7$ & $4.4 \pm 0.7$ \\
100 & $5.1 \pm 0.8$ & $7.9 \pm 2.2$ \\
\hline
\end{tabular}

Table 2. The cells were exposed to SNP $(10 \mu \mathrm{M})$ and/or IBMX $(1000 \mu \mathrm{M})$. The combination of SNP and IBMX caused complete cell death after 5 days. The assay of $\mathrm{cGMP}_{\text {in }}$ and $\mathrm{cGMP}_{\mathrm{ex}}$ were performed after 3 days. The results are presented as mean value $\pm \operatorname{SEM}(n=3)$.

\begin{tabular}{|c|c|c|}
\hline & $\mathrm{cGMP}_{\text {in }} \mathrm{pmol} / 10^{7}$ cells & $\mathrm{cGMP}_{\mathrm{ex} / \mathrm{in}}$ \\
\hline Control & $5.2 \pm 0.8$ & $2.6 \pm 0.9$ \\
\hline SNP & $7.6 \pm 1.7$ & $4.7 \pm 0.9$ \\
\hline IBMX & $9.3 \pm 0.4$ & $16 \pm 1.9$ \\
\hline SNP + IBMX & $14 \pm 1.8$ & $84 \pm 5.5$ \\
\hline
\end{tabular}

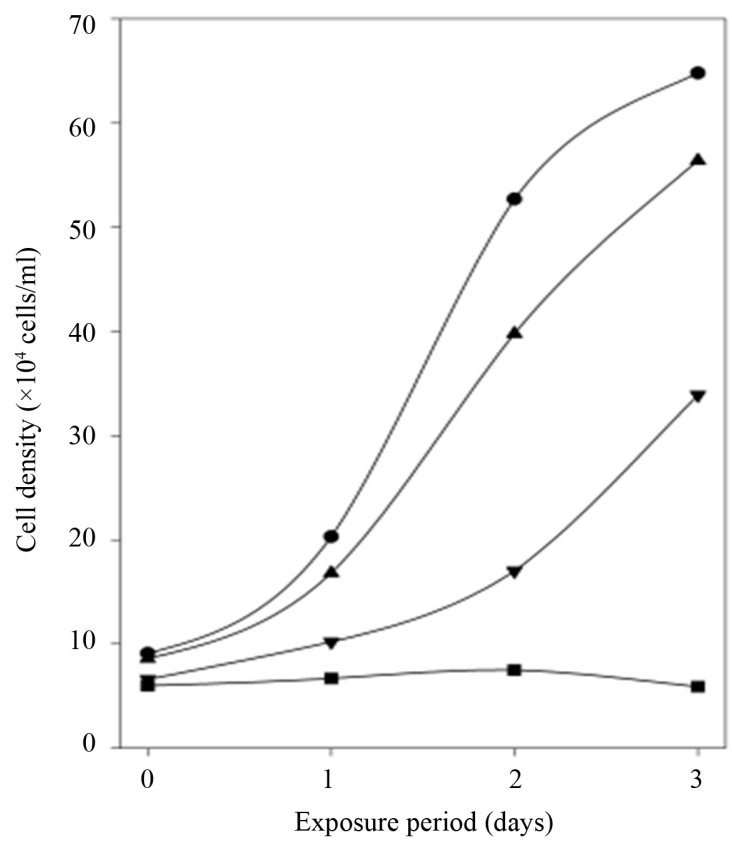

Figure 2. After removal of old medium freshly prepared SNP $(10 \mu \mathrm{M})$ and/or IBMX $(1000 \mu \mathrm{M})$ was added daily to HEK293 cells in culture. After 3 days the baseline cell densities had increased from $3.9 \pm 1.0 \times 104$ to $52.7 \pm 4.0$ $\times 104$. The results are presented as cell density (mean) from three time-independent experiments. Control $(\bullet), 10$ $\mu \mathrm{M}$ SNP $(\boldsymbol{\Delta}), 1000 \mu \mathrm{M} \operatorname{IBMX}(\boldsymbol{\nabla})$ and $10 \mu \mathrm{M}$ SNP + $1000 \mu \operatorname{M~IBMX}(\mathbf{\square})$. 
for the cGMP transporter due to intracellular PDE inhibition and secondly, reduced hydrolysis of cGMP ex $_{\text {by }}$ inhibition of extracellular PDEs released from dead cells. The extracellular IBMX levels were similar after the second $(750 \pm 19 \mu \mathrm{M})$ and third day $(680 \pm 52 \mu \mathrm{M})$. The intracellular IBMX concentrations after the second day were $85 \pm 21 \mu \mathrm{M}$, based on a cellular volume $\left(\sim 1 \mu \mathrm{l} / 10^{6}\right.$ cells) as reported previously [11]. The addition of SNP had no distinct effect on the IBMX concentrations (results not shown).

Glutathione (GSH) protects cells against oxidative stress which are created by SNP [20]. Since SNP consumes GSH during the formation of S-nitrosoglutathione the intracellular levels of GSH and GSSG were determined after repeated exposure to $100 \mu \mathrm{M}$ SNP. The respective base-line values of cellular GSH or GSSG after 5 days were $25 \pm 4$ and $0.10 \pm 0.01 \mathrm{nmol} / \mathrm{mg}$ protein. This corresponds to a GSH/GSSG ratio of $260 \pm 32$. After exposure to $100 \mu \mathrm{M}$ SNP the GSH levels were virtually unchanged (32 $\pm 2 \mathrm{nmol} / \mathrm{mg}$ protein) but with a clear increase in GSSG levels $(0.39 \pm 0.05 \mathrm{nmol} / \mathrm{mg}$ protein). The GSH/GSSG ratio declined to $84 \pm 8$.

\subsection{Exogenously Added cGMP, Cell Growth, and Levels of cGMP, GSH and GSSG}

In order to determine the ability to mimic the SNP effect on cell growth cGMP was added to the culture medium in concentrations up to $1000 \mu \mathrm{M}$ since cell membranes are virtually impermeable for cyclic nucleotides from the ectoside at physiological concentrations. Figure 3 shows that cell proliferation was inhibited in a concentration-dependent manner by cGMP. The addition of $10 \mu \mathrm{M}$ cGMP gave no distinct inhibition compared to baseline values of cell densities (Figure 3) or cGMP in (Table 3). After 5 days with cGMP added to the culture medium the cell densities were reduced to $63.3 \% \pm 3.0 \%$ of the baseline values. An intracellular concentration of approximately $20 \mu \mathrm{M}$ was obtained. In contrast to the experiments with SNP, addition of cGMP to the culture medium hampered the use of cGMP $_{\text {ex/in }}$ as a surrogate marker for cGMP efflux.

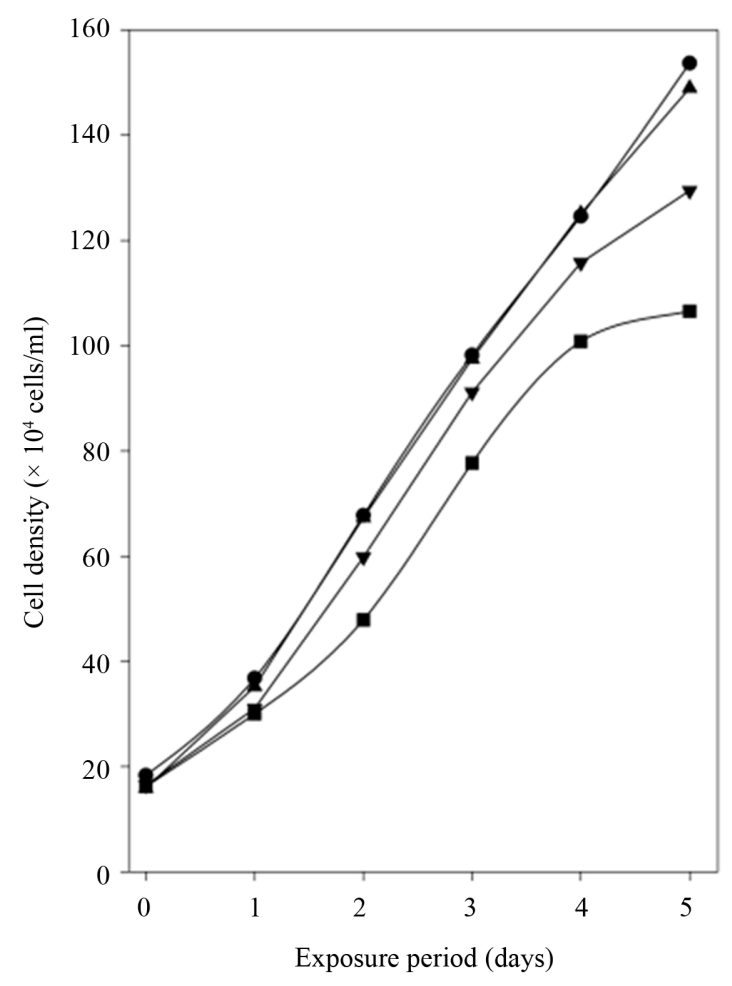

Figure 3. After removal of old medium cGMP was added daily to HEK293 cells in culture. The baseline cell densities increased from $6.4 \pm 1.2 \times 104$ to $143.5 \pm 6.7 \times$ 104 cells/ml after 5 days. The results are presented as cell density (mean) from six time-independent experiments. Control $(\bullet), 10 \mu \mathrm{M}(\boldsymbol{\Delta}), 100 \mu \mathrm{M}(\boldsymbol{\nabla})$ and 1000 $\mu \mathrm{M} \mu \mathrm{M}(\mathbf{\square}) \mathrm{cGMP}$. 
Table 3. Cyclic GMP was added daily and the intraand extracellular concentrations were determined $24 \mathrm{~h}$ after the addition. The results after 5 days exposure are presented as mean value \pm SEM $(n=6)$.

\begin{tabular}{|c|c|c|}
\hline cGMP $\mu \mathrm{M}$ & $\mathrm{cGMP}_{\text {in }} \mathrm{pmol} / 10^{7}$ cells & $\mathrm{cGMP}_{\text {ex/in }}$ \\
\hline 0 & $5.3 \pm 0.8$ & $1.4 \pm 0.3$ \\
\hline 10 & $7.4 \pm 1.3$ & $7.5 \pm 2.2$ \\
\hline 100 & $44 \pm 11$ & $35 \pm 5.2$ \\
\hline 1000 & $195 \pm 19$ & $50 \pm 4.9$ \\
\hline
\end{tabular}

In separate experiments we tested the ability of IBMX to modulate the effect of cGMP added to the culture medium. The cell cultures were supplemented with $1000 \mu \mathrm{M}$ cGMP and/or $1000 \mu \mathrm{M}$ IBMX daily. In order to compare these results with that of SNP in combination with IBMX (Figure 2) the cells were harvested after three days repeated exposure. Alone, cGMP and IBMX gave a cell density reduction of approximately $10 \%$ and $40 \%$, respectively. However, a synergistic effect occurred when cGMP and IBMX were combined with a reduction in cell densities of about $85 \%$ (Table 4). Similar values for $\mathrm{CGMP}_{\text {in }}$ and cGMP ex/in $_{\text {in }}$ were observed in the two time-independent experimental series for baseline and IBMX series (Tables 2 and 4). The presence of IBMX increased $\mathrm{cGMP}_{\text {in }}$ and $\mathrm{cGMP}_{\text {ex }}$ with approximately $140 \%$ and $400 \%$, respectively. The IBMX concentrations in the culture medium were similar in the absence $(750 \pm 68 \mu \mathrm{M})$ and presence of cGMP $(820 \pm 73 \mu \mathrm{M})$.

The GSH levels were not affected after five days exposure to $1000 \mu \mathrm{M}$ cGMP. The baseline levels and the levels after addition of cGMP were $25 \pm 4$ and $28 \pm 4 \mathrm{nmol} / \mathrm{mg}$ protein, respectively. The concentrations of GSSG in absence $(0.10 \pm 0.01 \mathrm{nmol} / \mathrm{mg}$ protein) and presence of exogenously added cGMP $(0.15 \pm 0.04 \mathrm{nmol} /$ $\mathrm{mg}$ protein) showed no clear difference. In agreement with these observations, no difference between baseline GSH/GSSG ratios (260 \pm 32$)$ and after cGMP exposure (220 \pm 54$)$ was detected.

\subsection{Cyclic GMP Efflux from HEK293 Cells}

The baseline transmembrane cGMP concentration ratios ranged from 1.4 to 2.6 compatible with active transport out of cells. IOVs from the HEK293 cells were employed to characterize this process. The uptake of $\left[{ }^{3} \mathrm{H}\right]-\mathrm{cGMP}$ was ATP-dependent and saturable with a $\mathrm{K}_{\mathrm{m}}$ of $2.3 \pm 0.6 \mu \mathrm{M}$ and $\mathrm{V}_{\max }$ of $1.1 \pm 0.1 \mathrm{dpm} / \mu \mathrm{g}$ protein/min (mean value \pm SEM, $n=3$ ). This observation is compatible with one class of high affinity transporters.

\section{Discussion}

The present study showed that SNP was a potent anti-proliferative agent for HEK2933 cells. It modulates various key enzymes including sGC, PLC, PKC or PI3K. In addition these substances cause s-nitrosylation of intracellular proteins and have direct effects on gene expression, for review see [1]. The sGC pathway has been demonstrated by several in vitro studies wherein SNP and other sGC-stimulating agents inhibited the growth of VSMC in a dose dependent manner [2]-[5]. The peak concentration of cGMP after SNP stimulation of rat lung fibroblasts occurred after 3 - 5 min and then diminished [19]. In the present study the intracellular cGMP levels were measured $24 \mathrm{~h}$ after addition of SNP and it was not surprising that CGMP $_{\text {in }}$ had decreased and was similar to baseline values (Table 1) due to cellular cGMP efflux which is a unidirectional energy-dependent process with a low and high $\mathrm{K}_{\mathrm{m}}$ component [21]. In HEK293 cells high $\mathrm{K}_{\mathrm{m}}$ cyclic nucleotide transport has been reported between 20 and $600 \mu \mathrm{M}$ [11] but this is the first report on low $\mathrm{K}_{\mathrm{m}}$ transport, as far as we know. The calculated $\mathrm{K}_{\mathrm{m}}$ value for cGMP transport was identical to that reported for cellular export of cGMP mediated by MRP5 [10]. The unidirectional transport may explain why $\mathrm{CGMP}_{\mathrm{ex} / \mathrm{in}}$ was inversely related to the fraction of surviving cells after stimulation with SNP. Extracellular cGMP has been reported to be a sensitive marker for sGC stimulation in platelets [22].

The estimated intracellular baseline concentrations after five days were $0.2-0.5 \mu \mathrm{M}$. These values represent the sum of unbound and target bound signal molecule and make sense since the affinities for PDEs and protein kinase $\mathrm{G}$ range from 0.02 to $3 \mu \mathrm{M}$ [23]. In the present study only $2 \%$ - 4\% of cGMP in the highest added concentrations $(100-1000 \mu \mathrm{M})$ gave distinct elevations of intracellular levels. In human erythrocytes approximate- 
Table 4. After three days with daily addition of cGMP $(1000 \mu \mathrm{M})$ and/or IBMX $(1000 \mu \mathrm{M})$ the intra- and extracellular levels of cGMP were determined. The cells were harvested $24 \mathrm{~h}$ after the last addition. The results are presented as mean value \pm SEM.

\begin{tabular}{|c|c|c|c|}
\hline & Cell density $10^{4}$ cells $/ \mathrm{mlpmol} / 10^{7}$ cells & $\mathrm{cGMP}_{\text {in }}$ & $\mathrm{cGMP}_{\mathrm{ex} / \mathrm{in}}$ \\
\hline Baseline & $61 \pm 3.2$ & $3.4 \pm 0.4$ & $2.5 \pm 0.5$ \\
\hline cGMP & $57 \pm 3.6$ & $242 \pm 23$ & $61 \pm 5.4$ \\
\hline IBMX & $35 \pm 3.6$ & $8.1 \pm 1.0$ & $13 \pm 1.6$ \\
\hline cGMP & $9.2 \pm 1.9$ & $480 \pm 17$ & $88 \pm 14$ \\
\hline
\end{tabular}

ly $2 \%$ were recovered after loading the cells with $900 \mu \mathrm{M}$ [24]. In contrast to the time course of cGMP ${ }_{\text {in }}$ after SNP exposure the concentrations build up over several hours after exogenously added nucleotide with a maximal level late in the "dose interval" as indicated for human erythrocytes [24]. The difference in time course may explain why $\mathrm{CGMP}_{\text {in }}$ was $0.4-0.5 \mu \mathrm{M}$ after SNP exposure and $0.7-20 \mu \mathrm{M}$ after exogenously added cGMP (Tables 1 and 3).

The observation that IBMX reinforced the action of SNP and cGMP agrees with the idea that cGMP is able to promote growth inhibition in non-malignant cells. IBMX is a non-specific PDE-inhibitor [25] but was employed since it is a much weaker high affinity cGMP transport inhibitor [26] than sildenafil [27]. The cellular uptake of IBMX gave intracellular concentrations $(\approx 100 \mu \mathrm{M})$ clearly above those needed for inhibition of PDE $1-7$ and PDE 10 - 11 with IC $_{50}$-values 1 - $80 \mu \mathrm{M}$ [25]. Accordingly, an effective inhibition of PDE activity by IBMX was observed with considerable elevation of cGMP ${ }_{\text {in }}$ (Tables 2 and 4). The presence of IBMX caused a disproportionate increase of $\mathrm{cGMP}_{\mathrm{ex}}$ compared to $\mathrm{CGMP}_{\mathrm{in}}$. Inhibition of PDEs released from dead cells in the growth medium may account for this.

Several cGMP independent mechanisms have been reported for SNP action [28]-[31], among which the formation of S-nitrosoglutathione induces apoptosis [20]. The present observation that GSSG level increased and GSH/GSSG declined after exposure to SNP but not after addition of cGMP, supports such mechanism. However, the ultimate clinical effect of nitric oxide donors is still a puzzle, and the balance between desired and unwanted /adverse effects is still unsettled [1].

\section{Acknowledgements}

Thanks are due to the Norwegian Cancer Society for financial support. The technical assistance by Mrs. Elin Orvoll is acknowledged.

\section{References}

[1] Thippeswamy, T., McKay, J.S., Quinn, J.P. and Morris, R. (2006) Nitric Oxide, a Biological Double-Faced Janus-Is This Good or Bad? Histology and Histopathology, 21, 445-458.

[2] Garg, U.C. and Hassid, A. (1989) Nitric Oxide-Generating Vasodilators and 8-Bromo-cyclic Guanosine Monophosphate Inhibit Mitogenesis and Proliferation of Cultured Rat Vascular Smooth Muscle Cells. Journal of Clinical Investigation, 83, 1774-1777. http://dx.doi.org/10.1172/JCI114081

[3] Kariya, K., Kawahara, Y., Araki, S., Fukuzaki, H. and Takai, Y. (1989) Antiproliferative Action of Cyclic GMP-Elevating Vasodilators in Cultured Rabbit Aortic Smooth Muscle Cells. Atherosclerosis, 80, 143-147. http://dx.doi.org/10.1016/0021-9150(89)90022-1

[4] Pollman, M.J., Yamada, T., Horiuchi, M. and Gibbons, G.H. (1996) Vasoactive Substances Regulate Vascular Smooth Muscle Cell Apoptosis. Countervailing Influences of Nitric Oxide and Angiotensin II. Circulation Research, 79, 748756.

[5] Guh, J.H., Hwang, T.L., Ko, F.N., Chueh, S.C., Lai, M.K. and Teng, C.M. (1998) Antiproliferative Effect in Human Prostatic Smooth Muscle Cells by Nitric Oxide Donor. Molecular Pharmacology, 53, 467-474.

[6] Wharton, J., Strange, J.W., Moller, G.M., Growcott, E.J., Ren, X., Franklyn, A.P., Phillips, S.C. and Wilkins, M.R. (2005) Antiproliferative Effects of Phosphodiesterase Type 5 Inhibition in Human Pulmonary Artery Cells. American Journal of Respiratory and Critical Care Medicine, 172, 105-113. http://dx.doi.org/10.1164/rccm.200411-1587OC

[7] Tantini, B., Manes, A., Fiumana, E., Pignatti, C., Guarnieri, C., Zannoli, R., Branzi, A. and Galie, N. (2005) Antipro- 
liferative Effect of Sildenafil on Human Pulmonary Artery Smooth Muscle Cells. Basic Research in Cardiology, 100, 131-138. http://dx.doi.org/10.1007/s00395-004-0504-5

[8] Pilz, R.B. and Broderick, K.E. (2005) Role of Cyclic GMP in Gene Regulation. Frontiers in Bioscience, 10, 1239-1268.

[9] Chen, Z.S., Lee, K. and Kruh, G.D. (2001) Transport of Cyclic Nucleotides and Estradiol 17-Beta-d-glucuronide by Multidrug Resistance Protein 4. Resistance to 6-Mercaptopurine and 6-Thioguanine. The Journal of Biological Chemistry, 276, 3747-33754. http://dx.doi.org/10.1074/jbc.M104833200

[10] Jedlitschky, G., Burchell, B. and Keppler, D. (2000) The Multidrug Resistance Protein 5 Functions as an ATP-Dependent Export Pump for Cyclic Nucleotides. The Journal of Biological Chemistry, 275, 30069-30074. http://dx.doi.org/10.1074/jbc.M005463200

[11] Wielinga, P.R., van der Heijden, I., Reid, G., Beijnen, J.H., Wijnholds, J. and Borst, P. (2003) Characterization of the MRP4-and MRP5-Mediated Transport of Cyclic Nucleotides from Intact Cells. The Journal of Biological Chemistry, 278, 17664-17671. http://dx.doi.org/10.1074/jbc.M212723200

[12] van Aubel, R.A., Smeets, P.H., Van Den Heuvel, J.J. and Russel, F.G. (2005) Human Organic Anion Transporter MRP4 (ABCC4) Is an Efflux Pump for the Purine End Metabolite Urate with Multiple Allosteric Substrate Binding Sites. American Journal of Physiology. Renal Physiology, 288, F327-F333. http://dx.doi.org/10.1152/ajprenal.00133.2004

[13] Akerboom, T.P. and Sies, H. (1994) Transport of Glutathione Disulfide and Glutathione S-Conjugates in Hepatocyte Plasma Membrane Vesicles. Methods in Enzymology, 233, 416-425. http://dx.doi.org/10.1016/S0076-6879(94)33048-4

[14] New, L.S. and Chan, E.C. (2008) Evaluation of BEH C18, BEH HILIC, and HSS T3 (C18) Column Chemistries for the UPLC-MS-MS Analysis of Glutathione, Glutathione Disulfide, and Ophthalmic Acid in Mouse Liver and Human Plasma. Journal of Chromatographic Science, 46, 209-214. http://dx.doi.org/10.1093/chromsci/46.3.209

[15] Stoscheck, C.M. (1990) Quantitation of Protein. Methods in Enzymology, 182, 50-68. http://dx.doi.org/10.1016/0076-6879(90)82008-P

[16] Keppler, D., Jedlitschky, G. and Leier, I. (1998) Transport Function and Substrate Specificity of Multidrug Resistance Protein. Methods in Enzymology, 292, 607-616.

[17] Bradford, M.M. (1976) A Rapid and Sensitive Method for the Quantitation of Microgram Quantities of Protein Utilizing the Principle of Protein-Dye Binding. Analytical Biochemistry, 72, 248-254. http://dx.doi.org/10.1016/0003-2697(76)90527-3

[18] Chou, T.C. (1976) Derivation and Properties of Michaelis-Menten Type and Hill Type Equations for Reference Ligands. Journal of Theoretical Biology, 39, 253-276. http://dx.doi.org/10.1016/0022-5193(76)90169-7

[19] Schroder, H., Leitman, D.C., Bennett, B.M., Waldman, S.A. and Murad, F. (1988) Glyceryltrinitrate-Induced Desensitization of Guanylate Cyclase in Cultured Rat Lung Fibroblasts. Journal of Pharmacology and Experimetal Therapeutics, 245, 413-418.

[20] Brune, B., von Knethen, A. and Sandau, K.B. (1998) Nitric Oxide and Its Role in Apoptosis. European Journal of Pharmacology, 351, 261-272. http://dx.doi.org/10.1016/S0014-2999(98)00274-X

[21] Sager, G. (2004) Cyclic GMP Transporters. Neurochemistry International, 45, 865-873. http://dx.doi.org/10.1016/j.neuint.2004.03.017

[22] Radziszewski, W., Chopra, M., Zembowicz, A., Gryglewski, R., Ignarro, L.J. and Chaudhuri, G. (1995) Nitric Oxide Donors Induce Extrusion of Cyclic GMP from Isolated Human Blood Platelets by a Mechanism Which May Be Modulated by Prostaglandins. International Journal of Cardiology, 51, 211-220. http://dx.doi.org/10.1016/0167-5273(95)02427-X

[23] Francis, S.H., Busch, J.L., Corbin, J.D. and Sibley, D. (2010) cGMP-Dependent Protein Kinases and cGMP Phosphodiesterases in Nitric Oxide and cGMP Action. Pharmacology Reviews, 62, 525-563. http://dx.doi.org/10.1124/pr.110.002907

[24] Flo, K., Hansen, M., Orbo, A., Kjørstad, K.E., Maltau, J.M. and Sager, G. (1995) Effect of Probenecid, Verapamil and Progesterone on the Concentration-Dependent and Temperature-Sensitive Human Erythrocyte Uptake and Export of Guanosine 3',5' Cyclic Monophosphate (cGMP). Scandinavian Journal of Clinical and Laboratory Investigation, 55, 715-721. http://dx.doi.org/10.3109/00365519509075401

[25] Francis, S.H., Sekhar, K.R., Ke, H. and Corbin, J.D. (2011) Inhibition of Cyclic Nucleotide Phosphodiesterases by Methylxanthines and Related Compounds. Handbook of Experimental Pharmacology, 200, 93-133. http://dx.doi.org/10.1007/978-3-642-13443-2_4

[26] Schultz, C., Vaskinn, S., Kildalsen, H. and Sager, G. (1998) Cyclic AMP Stimulates the Cyclic GMP Egression Pump in Human Erythrocytes: Effects of Probenecid, Verapamil, Progesterone, Theophylline, IBMX, Forskolin, and Cyclic AMP on Cyclic GMP Uptake and Association to Inside-Out Vesicles. Biochemistry, 37, 1161-1166. 
http://dx.doi.org/10.1021/bi9713409

[27] Sundkvist, E., Jaeger, R. and Sager, G. (2002) Pharmacological Characterization of the ATP-Dependent Low $k_{m}$ Guanosine 3',5'-cyclic Monophosphate (cGMP) Transporter in Human Erythrocytes. Biochemical Pharmacology, 63, 945-949. http://dx.doi.org/10.1016/S0006-2952(01)00940-6

[28] Ishida, A., Sasaguri, T., Miwa, Y., Kosaka, C., Taba, Y. and Abumiya, T. (1999) Tumor Suppressor p53 But Not cGMP Mediates NO-Induced Expression of p21(Waf1/Cip1/Sdi1) in Vascular Smooth Muscle Cells. Molecular Pharmacology, 56, 938-946.

[29] Tanner, F.C., Meier, P., Greutert, H., Champion, C., Nabel, E.G. and Luscher, T.F. (2000) Nitric Oxide Modulates Expression of Cell Cycle Regulatory Proteins: A Cytostatic Strategy for Inhibition of Human Vascular Smooth Muscle Cell Proliferation. Circulation, 101, 1982-1989. http://dx.doi.org/10.1161/01.CIR.101.16.1982

[30] Tarr, J.M., Eggleton, P. and Winyard, P.G. (2006) Nitric Oxide and the Regulation of Apoptosis in Tumour Cells. Current Pharmaceutical Design, 12, 4445-4468. http://dx.doi.org/10.2174/138161206779010477

[31] Borutaite, V. and Brown, G. (2005) What Else Has to Happen for Nitric Oxide to Induce Cell Death? Biochemical Society Transactions, 33, 1394-1396. http://dx.doi.org/10.1042/BST20051394 